\title{
Pembelajaran Ramah Anak bagi Orang Tua dan Guru Taman Kanak-Kanak di Kecamatan Bontotiro
}

\author{
Muh. Yusri Bachtiar ${ }^{1}$, Azizah Amal $^{2}$, Rusmayadi ${ }^{3}$ \\ 1,2,3 Jurusan Matematika, Fakultas MIPA, Universitas Negeri Makassar
}

\begin{abstract}
This paper is the result of the Community Partnership Program (PKM) activity by presenting the use of Acrylic Manipulative Aids (APMA) for learning fraction concepts for math teachers. The purpose of the activity is to maximize active learning activities in the classroom and use teaching aids in mathematics learning activities. The target is for junior high school teachers in Bulukumba District where 21 people are involved in the activity. The form of activities is training, while implementation information is fulfilled by providing worksheets and questionnaires as response sheets for activities. The results of the training activities carried out received a positive response. Not only is APMA considered feasible as a medium of learning or teaching aids, but it can also be used to help students overcome difficulties in learning the concept of fractions, fraction operations consisting of addition, subtraction, multiplication, and division. In addition, by convincing the teacher to respond that APMA can complete the explanations contained in mathematics textbooks. In other words, in addition to learning by using learning resources derived from books, APMA is also useful to supplement the provision of understanding to students in the classroom.
\end{abstract}

Keywords: APMA, Fraction Concept, Community Partnership Program

\section{PENDAHULUAN}

Pada masa ini, masalah-masalah kebutuhan perkembangan pada anak merupakan sesuatu yang harus dan mutlak terpenuhi pada anak sesuai dengan perkembangan anak itu sendiri. Pemenuhan itu dapat tercapai bila dilakukan sesuai dengan karateristik anak itu sendiri. Lingkungan keluarga, masyarakat dan lembaga pendidikan sebagai bagian yang tidak terpisahkan dalam pemenuhan kebutuhan untuk anak bertumbuh dan berkembang.

Anak usia dini memiliki karakteristik yang khas, baik secara fisik, psikis, sosial, moral, spiritual maupun emosional. Anak usia dini merupakan masa yang paling tepat untuk membentuk fondasi dan dasar kepribadian yang akan menentukan pengalaman selanjutnya. Oleh karena itu memahami anak usia dini merupakan sesuatu yang sangat penting bagi para orang tua, guru, pemerintah, dan masyarakat pada umumnya. Melalui pemahaman tersebut sangat membantu mengembangkan mereka secara optimal sehingga kelak menjadi generasi-generasi unggul yang siap memasuki era globalisasi yang penuh dengan berbagai tantangan dan permasalahan yang semakin rumit dan kompleks.

Pengembangan program sekolah ramah anak ditujukan untuk memenuhi kebutuhan hak anak dan banyak di pengaruhi oleh lingkungan keluarga maupun lingkungan lainnya. Komar (2006) mengatakan meskipun anak dipengaruhi sangat besar oleh lingkungan keluarga, ia dapat menerima juga pengaruh dari lingkungan lainnya. Lingkungan pendidikan adalah tempat interaksi manusia dan kondisi alam dan kondisi sosial yang pada gilirannya dapat mengembangkan pengalaman pada diri anak yang bersangkutan.

Teori perkembangan pada Piaget dengan konsep kecerdasan seperti halnya sistem biologi membangun struktur untuk berfungsi, pertumbuhan kecerdasan ini dipengaruhi oleh lingkungan fisik dan sosial, kematangan dan ekuilibrasi. Semua organisme dilahirkan dengan kecenderungan untuk beradaptasi menyesuaikan diri dengan lingkungannya. Cara beradaptasi berbeda bagi setiap individu, begitu juga proses dari tahap yang satu ke tahap yang lain dalam satu individu. Piaget selain meneliti tentang proses berpikir di dalam diri seseorang ia juga dikenal dengan konsep bahwa pembangunan struktur berfikir melalui per- 
kembangan kognitif anak menjadi empat tahap, yakni tahap sensori motor, (1) tahap lahir- 2 tahun, (2) tahap praoperasi, usia 2-7 tahun.

Menurut Piaget, tahapan ini sudah baku dan saling berkaitan, tidak dapat ditukar atau dibalik karena tahap sesudahnya melandasi terbentuknya tahap sebelumnya. Akan tetapi terbentuknya tahap tersebut dapat berubah-ubah menurut situasi sesorang, perbedaaan antar tahap sangat besar, karena ada perbedaan kualitas pemikiran yang lain. Meskipun demikian unsur dari perkembangan sebelumnya tetap tidak dibuang. Jadi ada kesinambungan dari tahap ke tahap, walaupun ada juga perbedaan yang sangat mencolok. Adaptasi terjadi dalam proses asimilasi dan akomodasi. Kita merespon dunia dengan menghubungkan pengalaman yang diterima dengan pengalaman masa lalu kita (asimilasi), sedangkan setiap pengalaman itu berisi aspek yang mungkin saja barusama sekali. Aspek yang baru inilah yang menyebabkan terjadinya dalam struktur kognitif (akomodasi). Asimilasi adalah proses merespon pada lingkungan yang sesuai dengan struktur kognitif seseorang. Tetapi proses pertumbuhan intelektual tidak akan ada apabila pengalaman yang ditangkap tidak berbeda dengan skemata yang ada oleh sebab itu diperlukan proses akomodasi, yaitu proses yang merubah struktur kognitif. Konsep ini menjelaskan tentang perlunya guru memilih dan menyesuaikan materi berpijak dari ide dasar yang diketahui anak, untuk kemudian dikembangkan dengan stimulasi lebih luas, misalnya dalam bentuk pertanyaan sehingga kemampuan anak meningkat dalam menghadapi pengalaman yang lebih kompleks.

Vigotsky memandang bahwa sistem sosial sangat penting dalam perkembangan kognitif anak. Orangtua, guru dan teman berinteraksi dengan anak dan berkolaborasi untuk mengembangkan suatu pengertian. Jadi belajar terjadi dalam konteks sosial, dan muncul suatu istilah Zone of Prosimal Development (ZPD). ZPDP diartikan sebagai daerah potensial seorang anak untuk belajar, atau suatu tahap dimana kemampuan anak dapat ditingkatkan dengan bantuan orang yang lebih ahli. Daerah ini merupakan jarak antara tahap perkembangan aktual anak yaitu ditandai dengan kemampuan mengatasi permasalahan sendiri batas tahap perkembangan potensial dimana kemampuan pemecahan masalah harus melalui bantuan orang lain. Oleh karena itu dalam mengembangkan setiap kemampuan anak diperlukan scaffolding atau bantuan arahan agar anak pada akhirnya menguasai keterampilan tersebut secara independen. Dalam mengajar guru perlu menjadi mediator atau fasilitator dimana pendidik berada disana ketika anak-anak membutuhkan bantuan mereka. Mediatoring ini merupakan bagian dari scaffolding. Jadi walaupun anaksebagai pembelajar yang aktif dan ingin tahu hampir segala hal, tetapi dengan bantuan yang tepat untuk belajar lebih banyak perlu terus distimuluasi sehingga proses belajar menjadi lebih efektif. Vigotsky meyakini bahwa pikiran anak berkembang melalui mengambil bagian dalam dialog yang kooperatif dengan lawan yang terampil dalam tugas di luar Zone proximal development dan menggunakan apa yang dikatakan pendidik yang ahli dengan apa yang dilakukan.

Berbeda dengan Piaget yang memfokuskan pada perkembangan berfikir dalam diri anak (intrinsik), Vigotsky menekankan bahwa perkembangan kognitif seorang anak sangat dipengaruhi oleh sosial dan kebudayaan anak tersebut. Setiap kebudayaan memberikan pengaruh pada pembentukan keyakinan, nilai, norma kesopanan serta metode dalam memecahkan masalah sebagai alat dalam beradaptasi secara intelektual. Kebudayaanlah yang mengajari anak untuk berfikir dan apa yang seharusnya dilakukan.

Bahkan Montessori memandang perlunya dipersiapkan sebuah lingkungan sebagai tempat belajar anak, apakah berbentuk kelas, tempat bermain, atau sebuah kamar di rumah. Pada dasarnya ruang kelas merupakan tempat dimana anak dapat dengan bebas belajar sesuai minatnya, baik secara individual maupun kelompok. Bahkan Montessori percaya bahwa pembelajaran anak-anak berlangsung dengan baik melalui pengalaman sensory panca indera. la berpikir bahwa pendidik memiliki tanggung jawab untuk memberikan pengenalan tekstur, bunyi, dan bau yang luar biasa bagi anakanak. la juga percaya bahwa bagian dari pengalam- 
an panca indera untuk anak-anak adalah mengenalkan alat dan perkakas yang cocok dengan tangan mereka dan meja kursi yang sesuai dengan tubuh yang kecil lingkungan yang indah, teratur, permainan sensory merupakan bagian dari warisan buah pemikiran Montessori. Secara tegas, Montessori menekankan pentingnya pendidikan motorik sensori, dan bahasa bagi anak prasekolah. Gerakan-gerakan motorik akan membuat anak mengarahkan kebebasan yang berarti dan membuat anak menjadi lebih tenang, gembira, dan merasakan kepuasan. Pada pengembangan sensori anak, pendidikan diarahkan mampu meletakkan dasar kemampuan intelektual anak melalui pengamatan dan latihan yang terus menerus sambil melakukan perbandingan dan penilaian. Para pendidik anak usia dini hendaknya terlibat aktif dalam proses pendidikan anak. Pemberian kesempatan yang luas untuk anak-anak mengenali lingkungannya dengan cara bereksplorasi merupakan tugas utama para pendidik.

Merancang ruang kelas dengan rak-rak yang rendah dan terbuka berarti anak-anak dapat melihat apa yang ada dan mendapatkan apa yang diinginkan tanpa bantuan dari pendidik. Mereka tidak perlu mengganggu pekerjaan mereka untuk mendapatkan perhatian dari pendidik yang sibuk atau meminta ijin untuk menggunakan bahan-bahan yang mereka butuhkan. Seringkali dalam anakanak usia dini, persediaan bahan-bahan kegiatan disimpan di tempat yang tidak terjangkau oleh anak-anak. Pendidik yang mengikuti pedoman Montessori memiliki banyak sekali perbekalan yang tersedia untuk penggunaan anak-anak. Dengan bantuan dari anak-anak, mereka menyimpan perbekalan tersebut secara teratur sehingga pilihan dan kesempatan secara terusmenerus mengundang anak-anak untuk menjadi kreatif. Montessori juga sangat memperhatikan bagaimana menciptakan keindahan dan kerapian di ruang kelas. Menurut Montessori, mengetahui bagaimana merancang lingkungan yang indah dan menarik bagi anak-anak sama pentingnya dengan bagian pengajaran seperti mengetahui bagaimana memilih buku anak-anak yang baik untuk perpustakaan.
Dari pikiran Montessori, secara umum pada dasarnya pendidik anak usia dini adalah mempersiapkan lingkungan kondusif atau yang mendukung proses belajar, pertumbuhan pengembangan diri anak. Dalam hal ini pendidik tidak perlu memaksa atau membuat peraturan-peraturan yang mengikat anak tidak bebas dalam berekspresi. Pakar Psikologi perkembangan Erikson memfokuskan pada perkembangan psikososial sejak kecil hingga dewasa dalam delapan tahap. Setiap orang akan melewati tahapan dan setiap tahapan akan mendapatkan pengalaman positif dan negatif. Kepribadian yang sehat akan diperoleh apabila seseorang dapat melewati krisis dalam tugas perkembangan dengan baik.

Berdasarkan penjelasan di atas, pembelajaran ramah anak bagi guru TK merupakan salah satu mtode pembelajaran yang dilaksanakan di TK yang dicoba untuk dikembangkan dengan target untuk melatih guru-guru di TK dan menambah pengetahuan bagi orang tua anak dalam mendidik anak sewaktu dirumah. Melalui kegiatan pengabdian kepada masyarakat yang dilakukan kepada guru dan orang tua anak didik di TK Kabupaten Bulukumba, terdapat 2 permasalahan mitra yang teridentifikasi yaitu: 1) Guru belum memaksimalkan kegiatan pembelajaran aktif di sekolah maupun dirumah, 2) Guru belum maksimal memanfaatkan fasilitas alat peraga yang digunakan dalam kegiatan pembelajaran.

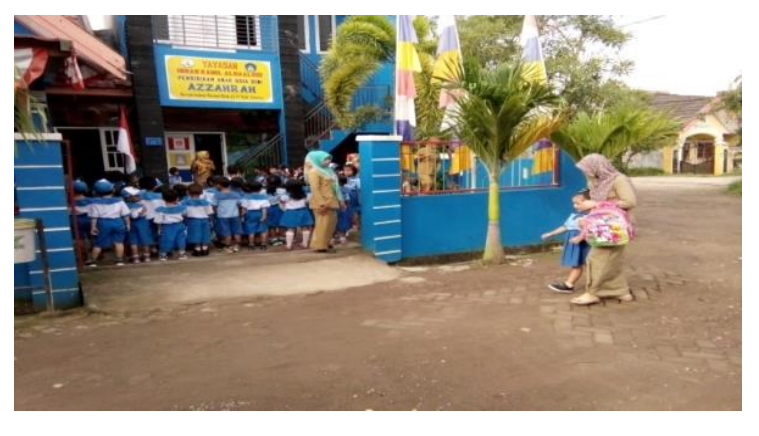

Gambar 1. Lokasi kegiatan

\section{METODE}

Dengan memperhatikan kedua masalah yang dikemukakan di atas, kegiatan pengabdian kepada masyarakat lebih dikenal sebagai Program Kemitraan Kepada Masyarakat (PKM) yang 
dilakukan dengan sasaran guru matematika tingkat SMP bertujuan untuk memaksimalkan kegiatan pembelajaran aktif di sekolah dan pemanfaatan fasilitas alat peraga dalam kegiatan pembelajaran yang Ramag terhadap anak. Untuk melaksanakan kegiatan PKM, terdapat dua rangkaian kegiatan yang diajukan yaitu meliputi sajian materi dan kegiatan praktek. Dalam penyajian materi peserta diberikan materi-materi mengenai konsep dasar PAUD, media pembelajaran, dan penggunaan media pembelajaran diligkungan pembelajaran yang ramah terhadap anak didik.

Pada bagian kegiatan praktikum peserta melakukan kegiatan praktek tentang pembelajarana ramah anak dilngkunag sekolah dan rumah, peserta melakukan presentasi dan diskusi tentang apa yang telah dikembangkan dalam praktikum dalam pembelajaran ramah anak tersebut.

Adapun kegiatan ini dilaksanakan di TK Kecamatan Bontotiro Bulukumba dengan melibatkan peserta sebanyak 15 orang.Untuk memperoleh informasi sejauhmana respon peserta terhadap kegiatan pengabdian kepada masyarakat terhadap peruntukan kegiatan yang dilakukan dan materi atau alat peraga yang disediakan, dilengkapi dengan beberapa instrumen, yaitu lembar kerja peserta kegiatan pelatihan, dan angket respon terhadap pelaksanaan kegiatan. Selama proses, dokumentasi tidak hanya diperoleh dari informasi melalui instrumen tersebut, tetapi juga foto selama kegiatan pelatihan berlangsung.

\section{HASIL DAN PEMBAHASAN}

Alat peraga manipulatif berbahan akrilik (APMA) adalah media pembelajaran matematika yang dibuat dari material akrilik. Ciri transparan yang dimiliki seperti kaca sehingga tampilannya yang bening serta bobot yang ringan sehingga ketika digunakan dalam aktivitas langsung (handson activities) lebih menarik dan mudah digunakan. Selain itu, permukaannya yang dapat berfungsi layaknya papan tulis sehingga pengguna dapat menulis di atasnya. Dalam kegiatan pembelajaran matematika, APMA ini dapat berfungsi sebagai tempat bekerja atau merekayasa konsep matematika sehingga misalnya siswa dapat langsung menggunakannya layaknya lembar kerja peserta didik (LKPD). Berikut ini adalah contoh APMA yang digunakan dalam kegiatan pengabdian kepada masyarakat, dan demonstrasi penggunaannya dalam kegiatan pembelajaran matematika di kelas.

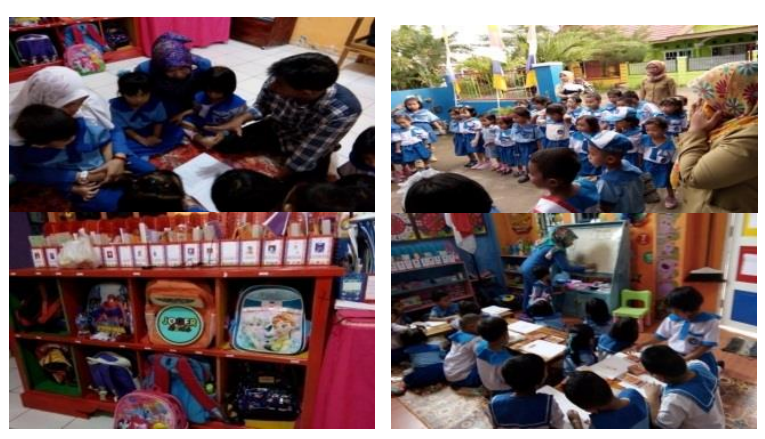

Gambar 2. Kegiatan model pembelajaran yang ramah terhadap anak

Melalui kegiatan PKM ini, proses pembelajaran ramah anak yang melibatkan kepada guru dan orang tua dalam suatu kegiatan pelatihan yang dilakukan sesuai rencana, yaitu pemberian materi dan dilanjutkan dengan kegiatan praktek. Seperti yang ditunjukkan ke dalam gambar di bawah ini.
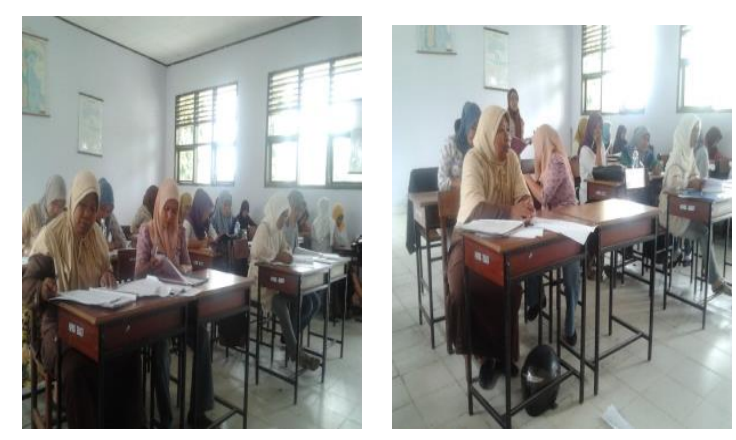

Gambar 3. Kegiatan pelatihan pembelajaran ramah anak bagi guru TK

Kegiatan pelatihan yang diperuntukkan bagi guru tingkat TK di Kecamatan Bontotiro Kabupaten Bulukumba juga mengumpulkan respon sebagaimana instrumen yang disiapkan. Hasil kegiatan pelatihan yang dilakukan dengan memperkenalkan dan mendemonstrasikan bagaimana konsep dasar pendidikan anak usia dini digunakan bagi guru, respon peserta pelatihan menunjukkan hal positif selama pelaksanaan. Namun, untuk 
memastikan bahwa pernyataan tersebut merupakan fakta yang ditemukan di lapangan, instrumen yang diberikan untuk mengidentifikasi dan menjaring pendapat guru yang tidak lain adalah praktisi pembelajaran matematika yang mengajarkan topik pecahan di kelas. Hasilnya disajikan pada Tabel 1.

Tabel 1. Respon guru terhadap pembelajaran topik pecahan di kelas

\begin{tabular}{llr}
\hline No & \multicolumn{1}{c}{ Indikator } & K2 \\
\hline 1 & Anak Memiliki Sikap Anti Kekerasan & $\mathbf{6 9 . 4}$ \\
\hline & $\begin{array}{l}\text { Anak memiliki sikap toleransi yang } \\
\text { tinggi }\end{array}$ & $\mathbf{6 1 . 8}$ \\
\hline 3 & Anak memiliki sikap peduli lingkungan & $\mathbf{7 4 . 3 1}$ \\
\hline 4 & Anak memiliki sikap setia kawan & $\mathbf{7 4 . 3 1}$ \\
\hline & $\begin{array}{l}\text { Anak memiliki sikap bangga terhadap } \\
\text { sekolah }\end{array}$ & $\mathbf{6 1 . 1}$ \\
\hline & Rata-Rata Semua Indikator & $\mathbf{6 8 . 1 8 4}$ \\
\hline
\end{tabular}

Dari tabel 1, informasi yang diperoleh adalah seperti apa yang dilakukan oleh anak tentang pembelajaran ramah anak di sekolah. Pernyataan pertama dimana anak beranggapan bahwa pembelajaran ramah anak masih dianggap sulit oleh orang tua anak. Begitu pula dengan pembelajaran tentaang pendidikan anak usia dini, terdiri atas teori perkembangan, bermain dan permainan, Bercerita, dan pendekatan sosial emosional masih dianggap sulit oleh anak.

Untuk mendukung kegiatan pembelajaran yang ramah terhadap anak di sekolah dan orang tua, maka guru menggunakan buku panduan tentang pembelajaran yang ramah terhadap anak dan lembar kerja. Setelah mengumpulkan pendapat tersebut, peserta pelatihan PKM pun diminta untuk memberikan pendapat mereka. Adapun respon mereka dirangkum ke dalam Tabel 2.

Dengan mengajukan 4 pernyataan yang digunakan untuk mengidentifikasi masalah yang dihadapi guru TK dalam pembelajaran ramah anak di sekolah, selanjutnya mereka diminta memberikan respon dengan melihat kegunaan teori dasar PAUD dalam mengatasi permasalahan guru terhadap pembelajaran ramah anak. Dengan melihat data yang ditunjukkan dari Tabel 2, kecenderungan positif ditunjukkan oleh setiap pernyataan yang diajukan. Untuk pernyataan 1 , ini penting untuk ditanggapi oleh guru dengan tujuan alat peraga yang didemonstrasikan dapat mengatasi permasalahan yang selama ini dihadapi. Misalnya dengan angka 3,35 (dalam interval 1-5) secara meyakinkan bahwa pembelajaran yang ramah terhadap anak dapat membantu mengatasi kesulitan dalam pembelajaran di TK. Begitu juga dengan kisaran 4,16-4,26, pembelajaran ramah anak dapat digunakan untuk membantu anak mengatasi kesulitan dalam belajar dengan teman-temannya.

Tabel 2. Respon guru terhadap pembelajaran

\begin{tabular}{cccccc}
\hline \multirow{2}{*}{ No } & \multirow{2}{*}{ Pernyataan } & \multicolumn{2}{c}{$\begin{array}{l}\text { Sangat } \\
\text { Setuju }\end{array}$} & \multicolumn{2}{c}{ Setuju } \\
\cline { 3 - 6 } & Frek & $\%$ & Frek & $\%$ \\
\hline 1 & $\begin{array}{l}\text { Mampu } \\
\text { memotivasi guru }\end{array}$ & 3 & 3,45 & 16 & 22.22 \\
\hline 2 & $\begin{array}{l}\text { Membuat Lebih } \\
\text { Aktif }\end{array}$ & 2 & 2.78 & 26 & 36.11 \\
\hline 3 & $\begin{array}{l}\text { Efektif Untuk } \\
\text { Diterapkan }\end{array}$ & 4 & 4,57 & 20 & 27.78 \\
\hline 4 & $\begin{array}{l}\text { Meningkatkan } \\
\text { Semangat Belajar }\end{array}$ & 3 & 4.17 & 5 & 6.94 \\
\hline & Total (\%) & 5 & 6.94 & 67 & 93.06 \\
\hline
\end{tabular}

Selama kegiatan PKM dilaksanakan terdapat 2 faktor yang memberikan pengaruh, yaitu pendukung dan penghambat. Penting untuk diketahui kedua faktor ini sebagai informasi yang dapat diperhatikan dalam pelaksanaan kegiatan yang serupa. Untuk faktor pendukung, berdasarkan hasil pelaksanaan PKM dapat dikemukakan 2 hal yang mendukung sehingga kegiatan ini dapat terlaksana dengan baik, yaitu Sehingga idealnya seorang pendidik PAUD di taman kanak-kanak perlu memahami hal yang sangat dibutuhkan dalam pembelajaran anak dan juga sangat perlu tahu bagaimanakah pendekatan yang dilakukan dalam menghadapi anak dalam proses pembelajaran di lingkungan PAUD. Tegasnya, Pembelajaran ramah anak merupakan sebuah pembelajaran yang menekankan agar seorang guru lebih kreatif. Kreativitas yang dimiliki seorang guru ini sebagai salah satu solusi penerapan dan pengembangan pembelajaran ramah anak di satuan PAUD, yang sampai saat ini belum semua dapat diimplementasikan secara keseluruhan oleh satuan PAUD. 
Guru juga harus lebih aktif dan mampu memanfaatkan perkembangan ilmu pengetahuan dan teknologi untuk mengembangkan model pembelajaran serta memanfaatkan media dan lingkungan sehingga mampu mengaplikasikan pembelajaran ramah anak dilingkungan PAUD.

Namun demikian, kegiatan PKM ini menjadi salah satu pelatihan yang memberikan nilai tambah bagi guru. Selain memberikan penyegaran pengetahuan kepada guru tentang pembelajaran aktif, juga pengembangan alat peraga manipulatif yang dapat digunakan untuk pembelajaran matematika topik pecahan. Sekaligus ini sejalan dengan menjawab tantangan yang dikemukakan oleh Aksu (2016).

\section{KESIMPULAN}

Kegiatan PKM yang dilaksanakan pada TK yang ada di Kecamatan Bontotiro Kabupaten Bulukumba dengan menyajikan tentang pembelajaran yang ramah terhadap anak. Kegiatan ini bertujuan untuk memaksimalkan kegiatan pembelajaran aktif di sekolah dan lingkungan sekolah maupun di rumah dengan pemanfaatan fasilitas alat peraga yang sudah ada di sekolah.

Hasil kegiatan pelatihan yang dilakukan dengan Pembelajaran berbasis ramah anak pada lingkungan PAUD digunakan untuk memperbaiki praktek penyelenggaraan PAUD yang masih banyak melakukan tindakan yang tidak ramah terhadap anak. Model pembelajaran berbasis ramah anak memiliki nilai-nilai yang konsisten sesuai dengan kebutuhan pembelajaran anak pada lingkungan PAUD. Model ini menekankan pada kemampuan guru dalam mengelola pemebelajaran di lembaga PAUD. Kemampuan tersebut, yakni kemampuan guru dalam melakukan persiapan pembelajaran, saat melakukan penyambutan terhadap anak, menentukan densitas main, menata lingkungan main, kemampuan guru dalam berinteraksi dengan anak didik dalam proses pembelajaran, dan kemampuan guru dalam mengajak anak untuk beres-beres dan recalling.

Setelah memperkenalkan aktifitas guru dalam model pembelajaran ramah anak pada lingkungan pendidikan anak usia dini yang telah diujicobakan pada Taman Kanak-Kanak Azzahrah Kelompok B terlaksana dengan baik. Begitu juga keterlaksanaan model pada saat ujicoba berada pada kategori baik. Hal yang sama juga ditemukan pada respon guru terhadap pembelajaran ramah anak pada lingkungan PAUD bagi anak taman kanak-kanak kelompok B berada pada kategori positif yaitu "sangat baik atau sangat setuju.

\section{UCAPAN TERIMA KASIH}

Kami mengucapkan terimakasih kepada Fakultas Ilmu Pendidikan (FIP) UNM, Lembaga Penelitian UNM, dan UNM yang telah memfasilitasi pendanaan pelaksanaan pengabdian kepada masyarakat ini melalui dana PNBP. Untuk kelompok guru TK di Kabupaten Bulukumba, kami mengucapkan terimakasih atas kerjasama baik guru maupun siswa yang telah memberikan bantuan berharga selama pelaksanaan pengabdian.

\section{DAFTAR PUSTAKA}

Aksu, M. (2016). Student Performance in Dealing With Fractions, (June). https://doi.org/10.1080/00220671.1997. 10544595.

Komar Oong, 2006. Filsafat Pendidikan Nonformal, Bandung: Pustaka Setia. 